\title{
So, you want to run the lab?
}

\author{
Warren K. Sinclaii
}

Handbook of Research Laboratory Management. By Virginia P. White. ISI Press, PhiladelphialAdam Hilger, Bristol: 1988. Pp. 240.\$49.95, £43.

IN MOST corporate enterprises there is the tacit assumption that even the youngest new employee at the foot of the ladder can climb the rungs and become the corporate head. It is expected that most employees will dream about their ultimate success in climbing this ladder, even though it will rarely be fully realized, and much of the administration of such an organization is based on that assumption.

Nothing so comparatively simple is possible in the administration of science. Although they are far from oblivious to personal recognition, most scientists do not care to occupy administrative posts themselves and sometime lack respect for those who do. Many chafe at administrative controls and even delight in circumventing them. In a well-run laboratory, research scientists tend to take for granted that supplies will always be available, that if they want a new $p \mathrm{H}$ meter it will be obtainable, that

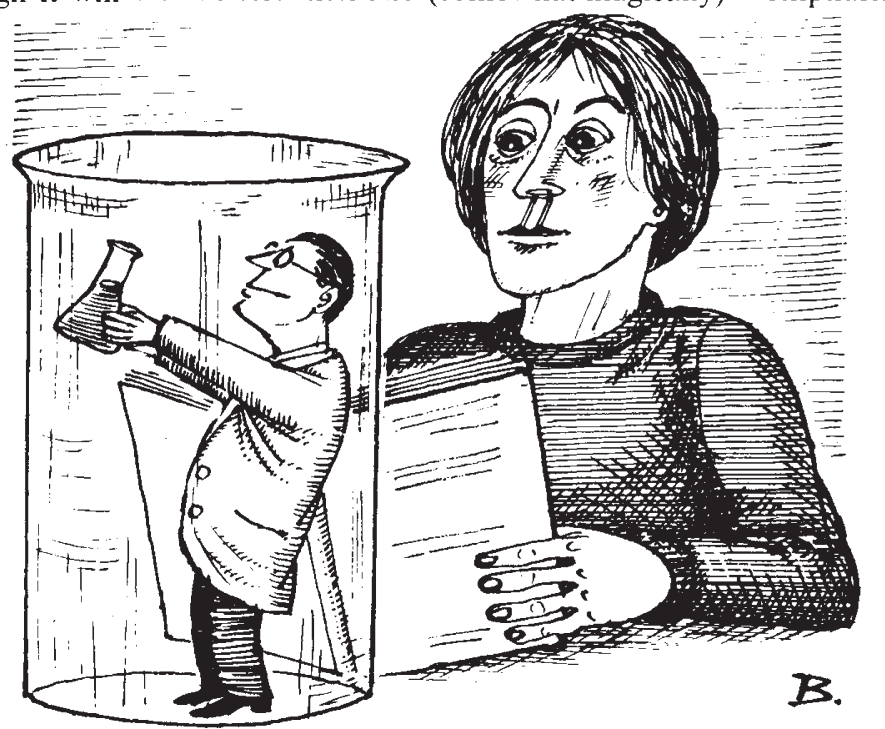

publication, safety, buildings, equipment and finance. Administrative services and how to run them are detailed. Even how to prepare for and run a scientific meeting is described in depth. Those responsible for purchasing or personnel, meetings or equipment, or library services could all learn something here about their job. And while the book mainly addresses the organization of large research laboratories, rather than university departments, its principles apply across the board. The author's emphasis is on practice in biological rather than physical laboratories, but the latter are not neglected.

Although many scientists do not care to be bothered about the details of administration, they do expect their own leaders to be scientists and (somewhat magically) ful division director of biology - at Oak Ridge National Laboratory (ORNL) - in the halcyon days of the Atomic Energy Commission (AEC). The author cites him frequently throughout, but oddly she does not refer to the vital role of the division director in relating to programme personnel at the headquarters (of the AEC) in Washington. This key function involves representing the programme and the new work of the laboratory division to the funding agency in both informal and formal ways. Hollaender was superb in this role and his research division flourished accordingly.

Three aspects of research staff management that Virginia White deals with deserve further comment. The first is her emphasis on the importance of involving researchers in every administrative proposal. Consultation with the research staff is vital to a successful laboratory. Good administrators know this; others can learn it here. The next concerns fallow periods in research workers' careers. Staff researchers in big laboratories, surrounded by able technical support, respected for past achievements and prominent in their favourite scientific society, nonetheless sometimes drift and need a new stimulus. Sabbaticals can be important but there are other ways, such as contact with students, especially graduate students, and teaching assignments at nearby universities.

The final aspect is the research support staff, who are invaluable in any laboratory. They are often longer-term employees than the research staff, develop skills in a lifetime of technical work that are critical to successful experiments, fix faltering equipment and generally to do all the 'man-Friday' work. Big laboratories tend to be excellent employers of such research assistants - they provide suitable titles, good working environments and better pay than most university programmes, where the problems experienced by non-faculty support staff are legend.

Omissions from the book are few, although some reference to bothersome items, such as security and quality assurance, and a more comprehensive treatment of radiation safety, would have been useful. The author ends with comments on the declining number of students entering science in the United States. This topic deserves much more discussion than is possible here but mention of it serves to point the finger at a serious problem. Equally serious may be the loss, due to budget cuts, of important areas of scientific expertise, for example in experimental carcinogenesis, in once broadly based organization of research, the important problems of communication in science,

That sensible if rather obvious theme flows through Virginia White's Handbook Wisely, the author does not attempt to put good administration before good science. However, the Handbook treats virtually every phase of its subject - from directors to research and administrative staff, the between laboratory and division directors. In big laboratories, the two roles are very different - the division head has much more control over scientific programmes and funding in his area than does the laboratory director, whose field is broad policy and the overall welfare of the entire organization. Alexander $\mathrm{Hol}$ laender was the quintessence of a success- 
laboratories of the type Hollaender used to direct.

The author draws heavily on her own experience at ORNL, at the Salk Institute and elsewhere but she also quotes widely from the experiences of many others in laboratory administration; indeed, the refreshing quotations to be found throughout the text relieve occasional tedium. These days, the administration of scientific research is a very special field. Virginia White brings out the elements of this speciality and provides a manual on how to do it well. Her Handbook will be a welcome guide to many, a substantial resource for others and interesting reading for many past and present laboratory administrators and research staff.

Warren K. Sinclair is President of the National Council on Radiation Protection and Measure ments, 7910 Woodmont Avenue, Suite 1016 Bethesda, Maryland 20814, USA. He was previously Associate Laboratory Director of Argonne National Laboratory, Argonn? Illinois.

\section{Minding business}

\section{Stuart Sutherland}

Molecules and Minds: Essays on Biology and the Social Order. By Steven Rose. Open University Press: 1988. Pp. I44. Hbk $£ 25 ; p b k £ 8.95$.

STEVEN Rose lives in a world of bogeymen and Aunt Sallies. He howls at reductionism, sociobiology, the bourgeoisie and determinism. In so far as his collection of essays has any general thesis, it is that current scientific work supports the capitalist status quo, which ought not to be supported; rather it should give way to some undefined form of socialism that would produce - all evidence to the contrary - Utopia.

According to Rose, "reductionism . . claims that in the long run higher order levels will be collapsed into the lower order ones; that they are 'nothing but' particularly complex systems to solving the problem of which the equations of the physicist are slowly approaching" (like many of his sentences, this one may need reading twice). Here as elsewhere he attacks something that no one, or almost no one, believes. The truth is that we will always require concepts appropriate to higher levels, no matter how much they are reducible. The hardness of a table top arises as an emergent quality from the way the atoms composing it are arranged and doubtless Steven Rose's angry writing arises from the way the neurons in his brain are arranged. But even if we fully understood his brain we would still need the term 'angry' to describe his behaviour. The reason why we cannot understand higher levels wholly in terms of lower ones lies in the nature of our own minds. We can consciously manipulate only a few concepts at once and, even though the table top is nothing but a vast collection of atoms, we cannot conceptualize its properties merely in terms of atomic activity; hence we need such concepts as hardness.

Having got reductionism all wrong, Rose suggests that it supports capitalism. The only instance he gives is that reductionism leads to putting the (lower-order) individual before the (higher-order) society, which he thinks is a bad thing though many would disagree with him.

Another of Rose's favourite targets is sociobiology. He condemns the whole subject, despite its brilliant account of the behaviour of ants and other social insects, but here his main quarry is Edward Wilson. When scientists, including Rose, stray from their field, they often say foolish things and Wilson is no exception, for having gone to the ant and studied her ways, he has not become wise. Rose attacks him for his tongue-in-cheek belief that a society in which sex differences were deliberately enhanced through conditioning would be happier than the present one. Without trying the experiment neither Rose nor anyone else has any means of knowing what the outcome would be. Oddly, he fails to pinpoint the two basic flaws in Wilson's popular writings. First, applying sociobiology to human affairs is for the most part pure speculation because little is known for certain about human genetics. Second, no amount of knowledge of that subject would tell us what is moral, though it might determine what is feasible.

It is unclear what Rose has against the much maligned bourgeoisie. Apparently they dominate others in rather a nasty way, but few will have noticed them doing this, unless of course voluntary work is a subtle form of domination. They make a large contribution to science, the arts, medicine and so on, but Rose is blind to their virtues. Nor does he stop to consider whether in his socialist Utopia a new bourgeoisie might arise, though if he were in charge he would doubtless take extreme measures to prevent it, for his book is redolent of Big Brother. For example, he would tell all scientists what to work on, though the projects would - he hopes be of social benefit. He implies that he would also make people live healthy lives, though it seems doubtful if abstaining from meat and dairy products, not to mention running a regimented ten miles before breakfast, would appeal to all members of the new Utopia. But then what others want is irrelevant - all that matters is what Rose thinks they ought to want.

Because he does not define the term, Rose's views on determinism cannot be explicated. Although he thinks it a bad thing, he seems to believe that behaviour is fully determined by the state of the brain. But then that is what he works on himself, as he describes in his final chapter which is almost the only one not given to obfuscation. His work seems to have affected his views on yet another moral issue. Because he gives both foot shock and electroconvulsive shock to animals, the Animal Liberation Movement is almost the only revolutionary campaign in Britain with which he does not side.

Rose not merely condemns the obiter dicta of scientists, many of which are admittedly rather silly, he actually believes that they influence politicians. He finds it hard to defend this thesis because the only examples he provides of politicians citing scientific evidence are the National Front and Enoch Powell. In fact, apart from the technological spin-off, work in biology and psychology has had remarkably little impact on political decisions. For example at a time when most psychologists thought IQ was mainly inherited, the American government launched Headstart, a programme to improve the IQ of disadvantaged children. Again, feminism arose and received considerable sympathy at just the time when some sociobiologists were telling women their place was genetically determined and they should stick to it. The thought of Margaret Thatcher sitting up at night reading the works of E. O. Wilson, Robert Trivers and John Maynard Smith is not without appeal, but one suspects it is unrealistic.

Even Rose's debating points don't seem to work. He writes, "Genes for altruism says Richard Dawkins are any that confer upon their possessors the property of acting 'altruistically". Rose comments "Genes for bad teeth in carnivores would result in their reducing their share of any common food resource to the benefit of others". He goes on to suggest it is absurd to define "bad tooth genes" as altruistic ones, having failed to notice that having a bad tooth is hardly an action.

Despite Rose's outcry, the truth is that science shapes neither morality nor government policy except in so far as new technologies can be applied. Nor, as Rose alleges, is science a particularly capitalist institution. Indeed capitalism itself is not necessarily a bad thing - it is hard to think of any other society in which the state, rightly or wrongly, has been more caring of its citizens than contemporary Britain. One suspects that people being what they are, there is no recipe for the perfect society for which Rose hankers. He might have done better to describe it rather than engage in the easier task of knocking down a few Aunt Sallies and attacking some particularly ineffectual bogeymen.

Stuart Sutherland is Director of the Centre for Research on Perception and Cognition, University of Sussex, Brighton BNI $9 Q G, U K$. 